\title{
The Urgency of Human Rights Audit on Mining Company in Indonesia
}

\author{
Hikmatul Ula \\ Junior Lecturer \\ Faculty of Law Brawijaya University \\ Malang, Indonesia \\ hikmah_ula@ub.ac.id
}

\begin{abstract}
Mining companies have the potential to violate human rights in conducting their business activities. The United Nations has issued Guide Line Principles in the business and human rights which essentially implements the principle of protection, respect and remedy of human rights issues. In the un-guidelines there is a company's obligation to conduct a human rights due diligence related to the business to be undertaken. Due diligence which is the obligation of the company must be followed by a human rights audit to ensure that due diligence works. This paper aims to analyze the importance of human rights audit on mining companies in Indonesia considering that in Indonesia there is still no comprehensive regulation in response to the UN Guidelines, so that the policies and implementation of human rights audit are limited and sectoral. With a conceptual and comparative approach, a legal comparison of the implementation of the existing human rights audit in the field of fishery industry in Indonesia is conducted. The human rights audit is the responsibility of the state to ensure that the mine does not violate due diligence. Human rights audit also serves as a performance report, especially in implementing responsibility to respect human rights. Human rights audit can be con ducted periodically along with annual reports by mining companies.
\end{abstract}

Keywords-audit, human rights, business ethic, mining company

\section{INTRODUCTION}

Indonesia is one of the mining investor's destination countries. Many foreign and local companies have engaged in the field of mining. Based on ESDM ministry records in 2016, the nu mber of companies with Mining License (IUP) is 9,721 companies [1], ${ }^{1}$. The mining sector is also a promising business as well as providing a substantial income for the country. The mining contribution amounted to 173.8 $\mathrm{T}(13 \%)[2]^{2}$ of the Indonesian State Budget in 2016.

Unfortunately, the number of mining companies is not balanced with good environmental conservation and equitable welfare improvement for communities around the mine. Mining companies actually commit human rights

${ }^{1} 6,335$ number of mining licenses are Clear and Clean $(\mathrm{CnC})$. Meanwhile, about 3,286 other mining licenses are still under reconciliation by the Governor.

2 The amount consists of: Tax revenue from oil and gas sector of $41.4 \mathrm{~T}$, non-tax state revenues

from Oil and Gas and Non-Oil and Gas of $124.9 \mathrm{~T}$ and sales revenue of mining products of 7.5 T. Source, Directorate of Budgeting, Directorate General of Budget Ministry of Finance, State Budget 2016 Information, abuses and environmental destruction. For examples: dozens of children in the hole former Samarinda mine [3] ${ }^{3}$, the case of PT. Mitrabara Adiperdana that damaged the environment in Malinau[4] $]^{4}$, the case of PT. Freeport and many more.

On the basis of many human rights abuses by the corporation, the United Nations provides guideline to corporation to apply the principles of human rights in running their business. In UN Guideline Principles on Business and Human Rights (hereinafter abbreviated UNGP on Business and HR) there are three main pillars that are regulated namely respect, protect and remedy. ${ }^{5}$ The first pillar is to encourage the government to Protect in business relations and human rights. The government's obligation to protect also includes ensuring that corporate activities do not violate human rights. In carrying out its duties the government can make regulations that regulate and require companies to respect and fulfill human rights .

The second pillar gives the company responsibility to respect human rights. In carrying out this responsibility, corporations are encouraged to avoid committing human rights violations. For that business actor must know the negative impact to human rights that can arise from business activity. Business actors are required to conduct a risk assessment through due diligence which contains the human audit and to communicate it to the stakeholders. The third pillar is the obligation for the government to provide remedy mechanisms through court and outside court in case of human rights violation by corporation.

In Indonesia, the creation of due diligence[5], 6 documents is defined in the narrow scope of the legal audit

3 The result of Human Rights Commission investigation shows that there are at least 70 holes of coal mine in Samarinda which are dangerous for the local people. The ex-mine holes in Samarinda and Kutai Kartanegara have at least claimed the lives of 12 children drowned. They are all children who drowned while playing in a pit mine area whose access is open to the public.

4 On July 4, 2017, the settling pond / sediment pond in Bet it pit belonging to PT Baradinamika Mudasukses (PT BM) collapsed and resulted in severe pollution in two major rivers in Malinau, Sesayap River and Malinau River. This pollution destroys local drinking water sources.

5 United Nation Guideline Principles on Business and Human Rights, New York and Geneva 2011

${ }^{6}$ Due diligence is a measure of prudence, activity, or assiduity, as is properly to be expected from, and ordinarily exercised by, a reasonable and prudent person under the particular circumstances; not measured by any absolute standard but depends on the relative facts of the special case." In other words, to a potential acquirer, due diligence means "making sure you get what you think you are paying for. 
document. This document is used only if the company wishes to merge, acquire, perform IPO or for other special purposes, $[6]^{7}$ and contains only procedural administrative matters.

In practice, the creation of legal audit documents does not include elements of a human rights audit. Hu man rights audit is not familiar compared to financial audit. This is because until now there is no regulation that requires the existence of human rights audit for companies, especially mining companies, both in the Law of Limited Liability Company No. 40 of 2007, Investment Law No. 25 of 2005, as well as regulations underit.

Related to the mining company, Clean and Clear $(\mathrm{CnC})$ certification was once regulated in Minister of Energy and Mineral Resources Regulation no. 34 of 2017 on Mining Licenses in the field of Minerals and Coal. The purpose of this $\mathrm{CnC}$ certificate is to know the company's compliance with the legal aspect, and its emphasis on the administrative aspect. Unfortunately, in 2018, CnC certificate as one of the requirements in submitting Mining Business License is removed, with the consideration to accelerate the process of licensing and simplification of regulations in ESDM Ministry[7].

Meanwhile, in the fishery sector, human rights certification is the main requirement in granting a fishery business permit. Based on the regulation of the Minister of Marine and Fisheries Affairs No. 35 of 2015 on the System and Certification of Human Rights on Fisheries Business requires Fishery Business Actors to have human rights certification and run their business in accordance with human rights standards.

Therefore HR Audit is very important as a follow up of due diligence. HR Audit is conducted to ensure that Corporations are running their business in accordance with human rights standards and prevention efforts have been made in the event of an impact on human rights violations

\section{HR AUdiT AS A GUARANTEE OF HUMAN RIGHTS IMPLEMENT ATION IN BUSINESS ACTIVITIES}

\section{A. Undestanding and Concept of HR Audit}

Audit is a science used to conduct an assessment of internal control which aims to provide protection and security in order to detect the occurrence of irregularities and irregularities committed by the company[8]. According to Mulyadi, the audit is a systematic process of obtaining and evaluating evidence objectively about statements regarding economic activities and events, with a view to establish the degree of conformity between the statements with predetermined criteria, and the delivery of the results to users concerned[9].

Audit can be done internally by employees or heads of a particular department and externally by an outside firm or an independent auditor. The idea is to check and verify the accounts by an independent authority to ensure that all books of accounts are done in a fair manner and there is no misrepresentation or fraud that is being conducted [10].

\footnotetext{
${ }^{7}$ Legal Audit is an examination and / or assessment of legal issues concerning or related to a company
}

In general, audits are used within the scope of finance. However, audits may also be used in other scopes according to audit objectives, including human rights audits. HR Audit may be included in the Compliance Auditing category. This audit is conducted to determine whether the company has complied with the rules and existing policies, both determined by the internal company (management, board of commissioners) and external parties (government, capital market supervisory bodies and financial institutions, Indonesian Bank, Directorate General of Taxes, and others other) including obedience in the as pect of human rights [8].

HR Audit itself is based on certain criteria as described in UNGP on Business and UN Global Compact. A company should develop quantifiable performance indicators to monitor and measure elements in its operations that have an impact on human rights. Performance indicators should measure both the direct result of the company's operations and the efficiency of management processes that influence performance - such as training and the allocation of resources.

The indicators should be relevant to the company's sphere of influence, activities, and industry sector, and should drive continuous improvement. They should relate to the organizational goals of the business and be consistent with the risks and opportunities that the company has identified. Measurements should be made regularly and be communicated to employees and other interested parties. Since a company's sphere of influence may change over time, performance indicators should be reviewed on a regular basis.

Human rights-based audit programs should be part of a company's governance procedures. Audits establish whether management systems are working as planned; they focus on the causes of problems and the necessary corrective measures. Human rights-based audits by qualified personnel, preferably verified by external human rights experts, should be carried out regularly and made publicly available. Auditing is also a tool for the Board and Executive Committee of a business to ensure that the strategies, policies, procedures, and processes outlined in this Guide have been properly implemented across the company [11].

\section{B. Internalizing HR Audit in Indonesia Legal System}

Guidelines are soft legal instruments, where their adherence is based on the awareness and willingness of each country. In the Indonesian legal system, international legal instruments not automatically can be enacted into national law, there must be a process of transformation from the form of international law into the appropriate form of national law. This is in accordance with the principle of dualis $m$ in the international law enforcement of national law[12].

To be able to apply the HR Audit as mandated in UNGP on Business and Human Rights, the government must make the transformation by incorporating important elements in the Guidelines into the law, either in the form of law or in the form of more technicalrules under it. ${ }^{8}$

\footnotetext{
${ }^{8}$ Article 9 (2) of Law No. 24/2000 on the International Treaty states that the ratification of an international agreement as meant in paragraph (1) shall be done by law or presidential decree. The election of a law or a presidential regulation is adapted to the content of the treaty.
} 
In order to run effectively, the implementation of HR Audit in Indonesia should pay attention to three aspects. The first aspect of its regulatory substance, the two aspects of the structure of the implementing agency of the rules, and the three aspects of people's readiness towards the enforcement of the rules [13]. ${ }^{9}$

The first aspect is the substance of legislation. The government should be able to internalize or transform the provisions of UNGP on Business and Human Rights in the form of appropriate legislation. The guideline is highly technical, so the appropriate form of transforming the guideline is in the Ministerial Regulation..$^{10}$ The Ministerial Regulation shall govern the technical provisions concerning the HR Audit, including the aspects to be audited and the auditor.

However, Ministerial Regulation could not be selfcontained. New ministerial regulations may exist if the above regulation wants them. The higher regulation of Ministerial Regulation is Government Regulation, and above it is the Law. ${ }^{11}$ As long as there is no Law or Government Regulation governing HR Audit then technical regulations could not be made. So the first thing to do is to include HR Audit in a Limited Liability Company Law, as well as CSR obligations.

The second aspect is the readiness of the structure or the implementing agency of the regulation. The government must prepare the system needed to implement the regulations. This system includes the hard system and soft system. Hard systems relate to institutional infrastructure, such as Audit institutions, supervisors and dispute settlements. This Human Rights Audit Institution may come from government or established by the government, but it can also be from an independent institution outside the government, eg private auditor, NGO and so on. Soft system related to the readiness of human resources. The government must prepare human resources who understand and are experts in application of human rights instruments in business. Therefore, human resources must be experienced and trained.

The third aspect is related to the readiness of the community towards the implementation of HR Audit. Basically, HR Audit created to ensure the rights of the community is not surrounded by their surrounding business activities. However, sometimes people do not understand how to defend their rights if their rights are violated. They do not understand the existing human rights mechanisms in business activities. Therefore HR Audit conducted should involve the community environment around business activities. The indigenous community becomes the main actor or key respondent to know how far the obedience of business actors to human rights instruments.

\footnotetext{
${ }^{9}$ Soerjono Soekanto states that there are five factors that determine the effectiveness of law enforcement in society, namely: the legal factor itself (law); law enforcement factors, that is, the parties that make up and apply the law; factors of supporting facilities or facilities; community factors; and cultural factors. In this case the authors simplify into three factors namely legislation rules, legal structure factors, and community culture

${ }^{10}$ Ministerial Regulation is a Regulation made by the Minister within the scope of its authority.

${ }^{11}$ Article 8 paragraphs 1 and 2 of Law No. 12 Year 2011 on the Establishment of the Laws and Regulations of the Invitation stipulates that the Ministerial Regulation is acknowledged to exist and has binding legal force as long as it is ordered by a higher Legal Regulation or established under the authority.
}

\section{HR CERTIFICATION AND HR AUDIT ON FISHERIES AND MINING COMPANY}

Following the revocation of the Clean and Clear certificate requirement as a condition of submission of Mining Business License, the mining sector practically does not have an instrument to measure the fulfillment of human rights. This is contrary to the policy of the fisheries sector which prioritizes the fulfillment of human rights in the granting of fishery business permit in the form of system and human rights certification on fishery business. The system and the Human Rights Certification are regulated in the Regulation of the Minister of Marine and Fisheries Affairs of the Republic of Indonesia Number 35/Permen-Kp/2015 on Human Rights System and Certification on Fishery Business.

The Ministerial Regulation stipulates that for any person or company that will apply for a fishery business permit must have a human rights certificate. The human rights certificate will be issued by the minister if the person or company has implemented a human rights system. The human rights system is the implementation of human rights policy, human rights examination, and human rights restoration. ${ }^{12}$

The Ministerial Regulation also regulates the supervision of human rights standards by the regulatory body to regulate compliance of fishery business actors against human rights instruments. The results of such supervision shall be submitted to the Minister as material to evaluate whether the permit will be forwarded or revoked. The criteria of Fisheries Compliance Rights in Ministerial Regulation are as follows:

\begin{tabular}{|l|l|l|}
\hline Scope of Audit & \multicolumn{1}{|c|}{ Issues } & \multicolumn{1}{|c|}{ HR Effected } \\
\hline & $\begin{array}{l}\text { - Does the company have } \\
\text { SOP of safety and health } \\
\text { for crew and workers } \\
\text { - Whether the company has } \\
\text { identified possible hazards } \\
\text { that threaten the safety of } \\
\text { workers and provides a } \\
\text { coping mechanism }\end{array}$ & $\begin{array}{l}\text { The right to } \\
\text { protection of } \\
\text { occupational safety } \\
\text { and health }\end{array}$ \\
$\begin{array}{l}\text { Occupational } \\
\text { safety and health }\end{array}$ & $\begin{array}{l}\text { - Has the company provided } \\
\text { appropriate } \\
\text { accommodation and } \\
\text { appropriate training for } \\
\text { workers }\end{array}$ & \\
& - etc \\
\hline \multirow{2}{*}{$\begin{array}{l}\text { Recruitment } \\
\text { System for Crew } \\
\text { and Workers }\end{array}$} & $\begin{array}{l}\text { SOPs on the recruitment of } \\
\text { crew and workers. }\end{array}$ & $\begin{array}{l}\text { The right to decent } \\
\text { and fair work }\end{array}$ \\
& $\begin{array}{l}\text { Does the company set } \\
\text { Ship Crews and fisheries } \\
\text { workers }\end{array}$ & \\
\hline
\end{tabular}

\footnotetext{
12 The Human Rights Policy is a statement that contains the commitment of the Fisheries Entrepreneur to respect the human rights of the parties related to the fishery business activities, including marine workers and the surrounding community.

Due Diligence Human Rights is a process undertaken by the Fisheries Entrepreneur to identify, assess, prevent, mitigate, and overcome the impact of human rights violations arising from the activities, operations and business relationships of the Fisheries Entrepreneur.

Human rights recovery is a process aimed at resolving the impact of human rights violations caused or participated in by the Fisheries Entrepreneur through an effective, judicial and non-judicial complaint mechanism.
} 


\begin{tabular}{|c|c|c|}
\hline & $\begin{array}{l}\text { - Does the company prepare } \\
\text { an appropriate and fair } \\
\text { labor contract for the crew } \\
\text { and fishery workers. } \\
\text { - etc }\end{array}$ & \\
\hline Labor system & $\begin{array}{l}\text {-Does the company } \\
\text { establish written rules on } \\
\text { employment relations in } \\
\text { union agreements } \\
\text { - Does the company enter } \\
\text { into a collective agreement } \\
\text { with a union agreement } \\
\text { with the union } \\
\text { - Etc }\end{array}$ & $\begin{array}{l}\text { - Right to freedom of } \\
\text { expression and } \\
\text { association } \\
\text { - Right to social } \\
\text { security } \\
\text { - The right to decent } \\
\text { and fair work }\end{array}$ \\
\hline $\begin{array}{l}\text { Responsibility for } \\
\text { sustainable } \\
\text { community } \\
\text { development }\end{array}$ & $\begin{array}{l}\text { - Does the company plan the } \\
\text { economic development } \\
\text { program of the } \\
\text { surrounding community } \\
\text { - Does the company have } \\
\text { SOPs related to the } \\
\text { company's land use } \\
\text { process in accordance with } \\
\text { applicable regulations }\end{array}$ & $\begin{array}{l}\text { - Right to self- } \\
\text { development } \\
\text { - Right to prosperity }\end{array}$ \\
\hline Security & $\begin{array}{l}\text { - Does the company ensure } \\
\text { that the security forces } \\
\text { used do not result in } \\
\text { human rights violation. }\end{array}$ & $\begin{array}{l}\text { - Right to security } \\
\text { - The right to personal } \\
\text { freedom }\end{array}$ \\
\hline Environment & $\begin{array}{l}\text { - Does the company already } \\
\text { have SOP related to toxic } \\
\text { hazardous waste } \\
\text { processing } \\
\text { - Has the company } \\
\text { implemented prevention } \\
\text { measures against } \\
\text { environmental damage }\end{array}$ & $\begin{array}{l}\text { - Right to have a } \\
\text { healthy and decent } \\
\text { living environment } \\
\text { - Right to prosperity }\end{array}$ \\
\hline Land Acquisition & $\begin{array}{l}\text { - Does the company have } \\
\text { SOPs to verify land } \\
\text { ownership } \\
\text { - Does the company have } \\
\text { procedures for land use } \\
\text { related to community land } \\
\text { - Has the company ensured } \\
\text { that the land used did not } \\
\text { seize or eliminate the } \\
\text { rights of the surrounding } \\
\text { community } \\
\text { - ect }\end{array}$ & $\begin{array}{l}\text {-Right to live } \\
\text { - Right to prosperity }\end{array}$ \\
\hline
\end{tabular}

There are three main things that HR Audit recommends to the mining company: the environment, the community around the company and the miners. All three are based on the magnitude of potential human rights violations or human rights impacts of mining activities.

\begin{tabular}{|c|c|c|}
\hline Scope of Audit & Issues & HR Effected \\
\hline Environment & $\begin{array}{l}\text { - Has the company } \\
\text { implemented safety and } \\
\text { safety standards for the } \\
\text { surrounding environment? } \\
\text { - Has the company met the } \\
\text { required waste management } \\
\text { standards? } \\
\text { - Does the company anticipate } \\
\text { the impact of environmental } \\
\text { pollution? } \\
\text {-Etc }\end{array}$ & $\begin{array}{l}\text { - Right to enjoy a } \\
\text { healthy } \\
\text { environment } \\
\text { - Right to live } \\
\text { comfortably } \\
\text { without threats }\end{array}$ \\
\hline
\end{tabular}

\begin{tabular}{|c|c|c|}
\hline $\begin{array}{l}\text { Indigenous } \\
\text { community }\end{array}$ & $\begin{array}{l}\text { - Does corporate activity } \\
\text { interfere with the lives of } \\
\text { indigenous peoples? } \\
\text {-Does the mining location } \\
\text { take over the rights of } \\
\text { indigenous peoples? } \\
\text { - Does the company prepare } \\
\text { anticipatory measures in case } \\
\text { of violations of the rights of } \\
\text { indigenous peoples? } \\
\text {-Is communication routinely } \\
\text { conducted with indigenous } \\
\text { peoples around the mine site? } \\
\text {-Etc }\end{array}$ & \begin{tabular}{|l}
-The right to live \\
and be recognized \\
as a part of society \\
- Right not to be \\
discriminated \\
against
\end{tabular} \\
\hline Labor & $\begin{array}{l}\text { - Has the company } \\
\text { implemented safet y and } \\
\text { security standards for } \\
\text { workers? } \\
\text {-Does the company give } \\
\text { workers the normative } \\
\text { rights? } \\
\text { - Does the company give } \\
\text { freedom of association and } \\
\text { opinion? } \\
\text {-Does the company involve } \\
\text { the worker's voice in making } \\
\text { important decisions within } \\
\text { the company? } \\
\text {-Does the company provide } \\
\text { health and welfare insurance } \\
\text { for workers? } \\
\text {-Etc. }\end{array}$ & $\begin{array}{l}\text { - The right to have } \\
\text { a decent } \\
\text { livelihood } \\
\text { - Right to be treated } \\
\text { fairly in industrial } \\
\text { relations } \\
\text { - Right to assembly } \\
\text { and opinion }\end{array}$ \\
\hline
\end{tabular}

In addition to these three main issues, HR Audit can be applied in more specific matters, such as related to women's and children's rights, or other issues according to the needs of each company.

HR Audit should be run periodically, at least once a year as in other audits, to know consistency and compliance with applicable rules. But ruling out HR Audit made for special purpose or on special request is not recommended. The HR Audit is performed by an independent, private, auditor, NGO, or agency appointed by the government to audit.

\section{CONCLUSION}

It should be understood that the fulfillment of human rights is a non-optional obligation. As all parties, the government, employers and the community must work together to support the achievement of human rights standards, as set out in UNGP on Business and Human Rights. So even though it is not regulated on human rights standards for mines, it can still refer to general human rights provisions.

Tactical steps that should be done by the government is to immediately enter the HR audit in legislation, UUPT, PP related to the company's obligations and the Minister of Energy and Mineral Resources. The duty of entrepreneurs related to responsibility to protect is to prepare reports related to business activities that intersect with human rights, the report contains at least three aspects of environmental impact, indigenous people, and workers. Reports on the fulfillment of human rights standards can be an assessment for the community against the activities of the company. If the company has complied with the standard, it can be dealt with firmly or closed. 


\section{REFERENCES}

[1] R. Prakoso, "ESDM: 2017, Jumlah IUP CnC Sekitar 3.000 Perusahaan," pusaka.or.id, 2016. [Online]. Available: http://pusaka.or.id/assets/2017/02/ESDM-2017-Jumlah-IUP-CnCSekitar-3-000-Perusahaan.pdf.

[2] “State Budget 2016," Directorate of Budgeting, Directorate General of Budget Ministry of Finance. [Online]. Available: https://www.kemenkeu.go.id/sites/default/files/bibfinal.pdf.

[3] "Ini Dua Kasus HAM di Kaltim," Newsbalikpapan, 2005. [Online]. Available: http://newsbalikpapan.com/ini-dua-kasus-ham-dikaltim.html

[4] A. Shahbanu, D. Pramudyana, and A. Saini, "Tambang Batubara Sokongan Jepang Menghancurkan Lingkungan Hidup di Malinau, Kalimantan Utara," 2017. [Online]. Available: http://www.jatam.org/wp-content/uploads/2017/11/PT-MitrabaraAdiperdana-Cemari-Sungai-Malinau.pdf.

[5] C. Mills, "Definition of Due Diligence," 2002. [Online]. Available: http://charlesmillsconsulting.com/due-diligence-definition.htm.

[6] "Legal Audit." [Online]. Available: http://www.hukumonline.com/klinik/detail/cl2861/legal-audit.
[7] "Simplification of Regulation in Ministry of Energy and Mineral Resources," Ministry of Energy and Mineral Resources, 2018. [Online]. Available: https://www.esdm.go.id/asset s/media/content/content-pencabutanpenyederhanaan-regulasi-dan-perizinan-sektor-esdm-.pdf.

[8] S. Agoes, Auditing: Petunjuk Praktis Pemeriksaan Akuntan dan Akuntan Publik (Practical Guide for Accountant and Public Accountant Inspection). Yogyakarta: Salambe Empat, 2012.

[9] A. Mulyadi, No Title. Yogyakarta: Salembe Empat, 2014.

[10] "The Understanding of Audit." [Online]. Available: https://economictimes.indiatimes.com/definition/audit.

[11] "Business Leaders Initiative on Human Rights, A Guide for Integrating Human Rights into Business Management," The UN Global Compact. [Online]. Available: file:///F:/HR and Mining/GuideHRBusinessen.pdf.

[12] H. Kelsen, Principle of Intemational lw. Clark New Jersey: Law Book Exchange, LTD, 2003.

[13] S. Soekanto, Faktor-Faktor yang Mempengamuhi Penegakan Hukum (Factors Affecting Law Enforcement). Jakarta: PT. Raja Grafindo Persada, 2008 